\title{
Nonmarket valuation of inner-city ecological values
}

\author{
P. Amrusch \& W. Feilmayr \\ Vienna University of Technology, University of Vienna, Austria
}

\begin{abstract}
Market-driven conservation of inner city green space improving people's quality of life also implicitly protects biological reserves. By using the hedonic pricing model as a revealed preference approach, people's willingness to pay for environmental attributes such as (natural) parks, plant species diversity and inner-city open space in general, is estimated for the city of Vienna (Austria). Thereby, hedonic price functions of citizens characterized by different incomes and preferences, respectively, are derived from housing prices. Consistent with previous literature findings, the estimated model suggests that people with different utility functions also attribute different values to environmental characteristics. In addition to the monetary valuation of nonmarket goods and services, conclusions about the relation between existence values and monetarily quantifiably environmental values (by the method of revealed preferences), entering in the inhabitant's utility functions, are drawn.
\end{abstract}

Keywords: environmental valuation, hedonic model, nonmarket valuation of natural parks, inner-city ecological values, biological reserves, plant species diversity.

\section{Introduction}

In theory, the hedonic pricing model (developed by Rosen [1]), as a revealed preference approach (originally introduced by Samuelson [2]), is able to monetarily quantify nonmarket values, i.e. to estimate perceived changes of a property's environmental characteristic. In particular, the hedonic model does not focus on the estimation of, e.g., existence values (knowledge that ecological values exist) or bequest values - which are not supposed to be reflected in the selected marketed good's price. Existence values may include intrinsic values, 
which are not preference-related in comparison to instrumental values (via human-held values). The intrinsic value would exist even if humans and their experiences were extinct [3]. However, if environmental attributes enter in the people's utility functions or, in other words, if people are implicitly willing to pay for environmental attributes, i.e. for green areas (which are capitalized in market values, e.g., in housing prices), in some cases the protection of related intrinsic or existence values - usually not fully entering in the people's utility functions, such as plant species diversity - may be supported. For instance, the inhabitant's willingness to pay for open space or green areas within Vienna may imply protection of plant-species diversity (as a subset of biodiversity) through the market-driven implicit conservation of green areas or inner-city open space. In particular, threatened bird species (i.e. the stock dove, the middle spotted woodpecker and the red-breasted flycatcher) are considered to be proprietary protected bird species, known to be potentially endangered and to be protected in Austria [4]. Studies show that the number of western jackdaws is higher in the districts of Vienna with a larger quantity of net green space - NGS (the percentage of the green surface per district) [5].

On the other hand, through the protection of bird species diversity, market values are created if people are implicitly willing to pay for additional amounts of green, e.g., as reflected in the housing market. Green areas as ecological values, among other factors, improve life quality in the city of Vienna, as supported by surveys [6,7], according to which the city of Vienna is rated among the world's first three most liveable cities, taking also into consideration ecological values. One aim of the paper is the investigation whether also inhabitants of the city of Vienna are implicitly willing to pay for environmental characteristics influencing their life quality, which are supposed to be reflected in a market good or service, such as housing. In this context, by using the hedonic pricing model, the marginal willingness to pay functions of individuals (supposed to display differentials in preferences and incomes) are derived for inner-city environmental characteristics, such as parks, open space, green areas, etc. Since people may not be always aware of the existence values in cities, such as plant species diversity, these values - compared to perceivable environmental characteristics (e.g., green areas) - may not be explicitly reflected in market prices of market goods and services and thus do not enter in the individuals' utility functions. Hence, this paper shows that plant species diversity increases the values of market goods, although they may directly enter in the individuals' utility functions.

Results of this study provide valuable insights for sellers and buyers of housing in Vienna. Furthermore, from the ecological point of view, results sustain public and private decision makers in the protection of environmental goods and services.

\section{Methodology and environmental valuation}

Several studies investigate the link between urban real estate or land prices and green areas, using the hedonic pricing technique. 
For instance, Morancho [8] estimates the price effect of the existence of views of a park or a public garden, the distance from the dwelling to its nearest green area and the size of that open space. Troy and Grove [9] showed that park proximity is positively valued by the housing market where the crime rate is below a certain threshold rate.

Gao and Asami [10] demonstrated that greenery of the neighbourhood significantly influences land prices in two Japanese cities. Des Rosiers et al. [11] found out that a positive tree cover differential between the property and its immediate neighbourhood translates into a higher housing value.

In this paper, the property price effect of inner-city ecological attributes (natural monuments, parks, etc.) is estimated by means of hedonic price regressions.

The estimated implicit marginal prices for the environmental characteristics are presumed to approximate the marginal willingness to pay for the environmental characteristics such as parks, natural monuments, biological reserves, since individuals are supposed to be similar in terms of preferences and income.

"The marginal purchase price function can be interpreted as a demand curve or a marginal willingness to pay function...a sufficient condition is equal incomes and identical utility functions for all" [12].

By investigating the willingness to pay for environmental characteristics in housing submarkets differentiating in the housing price level, Amrusch and Wirl [13] found out that individuals differing in income characteristics and preferences are supposed to differ also in terms of their location decisions and willingness to pay for environmental characteristics, i.e. air quality, respectively. Similarly, as noted by, e.g., Chay and Greenstone [14], holding other factors constant, equilibrium marginal willingness to pay for air quality seems likely to be higher for cleaner than for dirtier areas (even if they could be evaluated at a comparable level of emissions).

Thus, the study focuses on homogenous residential areas, in which buyers of houses are presumed to reveal similar preferences, based on self-selection of locations and housing qualities. By clustering the Vienna housing market into districts based on qualitative criteria, mean housing values of different housing categories per districts are employed as regressands.

\section{Empirical part}

\subsection{The data}

The use of disaggregated data allows for greater insights in the estimation results and the interpretation of the estimated environmental effects as the proxy for the marginal willingness to pay (willingness-to-pay-functions). However, from a "macro-perspective", on the basis of the qualitative partitioning of the city of Vienna into the 23 districts (due to inhomogeneities among certain districts, e.g., in terms of socio-economic characteristics), in this paper the relationship between environmental characteristics capitalized in the mean housing price of different submarkets is investigated. Similarly to Kong et al. [15], the averaged 
district apartment purchase price is employed as the dependent variable in the hedonic price regressions, allowing for the differentiation according to housing types representing the individuals' tastes and incomes. Average housing price levels per district are taken from the Austrian Immobilienpreisspiegel 2007 and 2008 [16] for four different apartment categories, denoted by PA, PB, PC, PD (standing for different accommodation qualities A - best, B - good, C - medium, and D - low).

Further environmental and neighbourhood explanatory variables with potential impact on housing prices, i.e. the number of gardens per district (in this case only gardens designated as "transportation areas" are taken into account) (GARDEN), the number of parcels of garden settlements per district (PGARDEN), the number of crimes per district (CRIME), the number of biological reserves (RESERVE) in terms of in hectares and in terms of the percentage of the total district area (including natural parks, biotopes, protected landscapes, gardens, etc.) have been collected; different types of traffic areas per district, such as public roads in square meters (ROADS), pedestrian areas in square meters, bicycle paths in meters (BICYCLE), the total number of firms per district and the number of firms subdivided according to the firm size per district (2005) and the number of natural monuments per district 2008 (NM) are obtained from the magistrate of the city of Vienna [17].

To point out a few examples of NMs, e.g., in the District II there can be found the Taxus baccata, the Populus nigra, the Fraxinus excelsior, the Populus alba, the Aesculus hippocastanum, the Ginkgo biloba, the Quercus robur, the Quercus cerris, whereas in the center (the District I) for Austria more unusual species grow, such as the Sophora japonica, the Pterocarya fraxinifolia, the Platanus orientalis, the Parotia persica, the Liriodendron tulipifera, the Fagus sylvatica "Laciniata", the Pterocarya fraxinifolia, the Ailanthus altissima. To mention some species in the peripheral and semicentral districts, in the District VII, i.e. the Corylus colurna and in the District XXI, i.e. the Picea abies can be detected.

The number of NMs per district (D) (2008) and medium apartment prices in $€$ for different apartment categories per district as well as the total number of inhabitants in 1000 per district in 2005 (INH) are displayed in table 1:

In addition, two dummy variables for inclusion into the regressions have been introduced. The location-specific dummy variable (DLOCATION) takes on the value 1 for the center, 0.5 for the semicentral districts and 0 for the peripheral districts. The second dummy variable represents the existence of biological reserves in a district, taking on the value 1 for a district with biological reserves (D_RES), and 0 otherwise. Additionally, the number of dogs (DOGS) per district in 2005 has been taken into consideration [17]. Information on the above mentioned NGS are gained from Donnerbaum [5].

\subsection{Estimation of effect of environmental attributes and neighbourhood characteristics on average housing values per district}

Using OLS, the estimated hedonic regression models for different housing categories, partially revealing individuals' income and tastes are given in tables 2 and 3 along with absolute t-statistics in parentheses. 
Table 1: $\quad$ Number of natural monuments and medium apartment prices in $€$ for different apartment types per district and the number of inhabitants per district.

\begin{tabular}{|c|c|c|c|c|c|c|c|c|c|c|}
\hline & 200 & 2008 & & & & 2007 & & & & 2005 \\
\hline DIST & NM & PA & PB & PC & PD & PA & PB & PC & PD & INH \\
\hline \# & \# & $€ / \mathrm{m}^{2}$ & $€ / \mathrm{m}^{2}$ & $€ / \mathrm{m}^{2}$ & $€ / \mathrm{m}^{2}$ & $€ / \mathrm{m}^{2}$ & $€ / \mathrm{m}^{2}$ & $€ / \mathrm{m}^{2}$ & $€ / \mathrm{m}^{2}$ & \# \\
\hline I & 13 & 4600 & 3225 & 2700 & 2100 & 4310 & 3298 & 2758 & 2177 & 17 \\
\hline IV & 5 & 2098 & 1810 & 1436 & 1216 & 2124 & 1850 & 1508 & 1214 & 30 \\
\hline $\mathrm{V}$ & 7 & 1958 & 1776 & 1408 & 1157 & 1846 & 1727 & 1383 & 1149 & 52 \\
\hline VI & 2 & 2250 & 1840 & 1543 & 1210 & 2321 & 1854 & 1507 & 1220 & 29 \\
\hline VII & 4 & 2208 & 1783 & 1545 & 1239 & 2201 & 1676 & 1587 & 1248 & 30 \\
\hline VIII & 6 & 2300 & 2038 & 1600 & 1213 & 2406 & 2131 & 1660 & 1326 & 24 \\
\hline IX & 7 & 2367 & 1849 & 1544 & 1284 & 2416 & 1821 & 1582 & 1296 & 39 \\
\hline II & 11 & 2148 & 1674 & 1384 & 1216 & 2122 & 1653 & 1366 & 1175 & 94 \\
\hline III & 11 & 2189 & 1861 & 1461 & 1141 & 2132 & 1817 & 1484 & 1064 & 84 \\
\hline $\mathrm{X}$ & 5 & 1688 & 1397 & 1143 & 959 & 1776 & 1392 & 1171 & 960 & 167 \\
\hline XI & 8 & 1640 & 1380 & 1165 & 975 & 1726 & 1454 & 1135 & 1021 & 83 \\
\hline XII & 10 & 1849 & 1538 & 1238 & 1054 & 1869 & 1491 & 1213 & 1053 & 84 \\
\hline XIII & 57 & 2673 & 2139 & 1721 & 1450 & 2559 & 2192 & 1703 & 1502 & 51 \\
\hline XIV & 33 & 2015 & 1711 & 1424 & 1133 & 1930 & 1635 & 1482 & 1101 & 83 \\
\hline $\mathrm{XV}$ & 6 & 1690 & 1520 & 1209 & 988 & 1713 & 1517 & 1190 & 923 & 70 \\
\hline XVI & 2 & 1887 & 1503 & 1250 & 1035 & 1924 & 1533 & 1265 & 1069 & 93 \\
\hline XVII & 11 & 2175 & 1711 & 1371 & 1117 & 2185 & 1712 & 1385 & 1077 & 52 \\
\hline XVIII & 21 & 2609 & 2164 & 1826 & 1458 & 2682 & 2227 & 1834 & 1477 & 47 \\
\hline XIX & 70 & 3021 & 2323 & 1819 & 1537 & 2829 & 2259 & 1802 & 1570 & 67 \\
\hline XX & 1 & 1753 & 1472 & 1230 & 921 & 1759 & 1425 & 1261 & 790 & 82 \\
\hline XXI & 9 & 1626 & 1366 & 1174 & 958 & 1662 & 1327 & 1147 & 919 & 136 \\
\hline XXII & 7 & 1695 & 1394 & 1179 & 908 & 1723 & 1334 & 1127 & 800 & 147 \\
\hline XXIII & 31 & 2049 & 1736 & 1340 & 1150 & 2004 & 1756 & 1350 & 1101 & 89 \\
\hline mean & 15 & 2195 & 1792 & 1466 & 1192 & 2183 & 1786 & 1474 & 1184 & 72 \\
\hline
\end{tabular}

Variables which are not highly correlated were not included into the regressions. Different functional forms (used in the literature [14]) were tested, whereby the lin-lin and the log-lin functional form were found to fit best to the data.

All variables below a $10 \%$ significance level in each regression were excluded, whereby some insignificant variables were maintained in the regressions. By using White-heteroskedasticity-consistent standard errors, the following estimates have been obtained, whereby the impact and significance of individual variables varies along with the dependent variable employed.

The fitting is satisfactory and similar in all regressions. The residuals are normally distributed according to the Jarque-Bera Test for normality.

Results show that natural monuments (NM) have a significant impact on the mean district apartment prices per square meter for each apartment category at a $1 \%$ significance level.

Interestingly, the price effect of natural monuments is similar (of around 7 percent) for high (A), good (B) and medium (C) quality apartments and 2008. The highest price impact of natural monuments of about 8 percent in 2007 is 
Table 2: $\quad$ Regressions using the average district apartment price per square meters for different apartment categories as dependent variable $(\mathrm{N}=23)$ (with absolute t-statistics in parentheses) in 2008.

\begin{tabular}{|r|r|r|r|r|}
\hline Constant and variables & Coefficients & Coefficients & Coefficients & Coefficients \\
\hline Constant & 7.428921 & 7.103971 & 7.299369 & 6.895366 \\
& $(48.5)$ & $(58.7)$ & $(65.0)$ & $(61.1)$ \\
\hline NM & 0.008337 & 0.006778 & 0.007145 & 0.006955 \\
& $(4.6)$ & $(4.7)$ & $(5.2)$ & $(5.1)$ \\
\hline BICYCLE*D & $-2.77 \mathrm{E}-06$ & $-1.58 \mathrm{E}-06$ & $-2.04 \mathrm{E}-06$ & $-1.68 \mathrm{E}-06$ \\
RESERVE & $(1.6)$ & $(1.0)$ & $(1.4)$ & $(1.3)$ \\
\hline ROADS & $7.98 \mathrm{E}-08$ & $4.03 \mathrm{E}-08$ & $6.94 \mathrm{E}-08$ & $3.53 \mathrm{E}-08$ \\
& $(2.6)$ & $(1.7)$ & $(3.7)$ & $(1.8)$ \\
\hline DOGS & $-8.21 \mathrm{E}-06$ & $-1.82 \mathrm{E}-05$ & $-2.34 \mathrm{E}-05$ & $-4.21 \mathrm{E}-06$ \\
& $(0.1)$ & $(0.4)$ & $(0.6)$ & $(0.1)$ \\
\hline GARDEN & 0.000144 & 0.000108 & 0.000107 & $5.93 \mathrm{E}-05$ \\
& $(2.0)$ & $(1.6)$ & $(1.8)$ & $(1.1)$ \\
\hline DLOCATION & 0.576474 & 0.477461 & 0.462393 & 0.453657 \\
& $(2.0)$ & $(2.0)$ & $(2.2)$ & $(2.2)$ \\
\hline Adj. R ${ }^{2}$ & .70 & .68 & .76 & .82 \\
\hline Dep. variable & $\log (\mathrm{PA})$ & $\log (\mathrm{PB})$ & $\log (\mathrm{PC})$ & $\log (\mathrm{PD})$ \\
\hline Jarque-Bera test & 2.6 & 7.6 & 5.6 & 4.8 \\
statistic & & & & \\
\hline
\end{tabular}

Table 3: $\quad$ Regressions using the average district apartment price per square meters for different apartment categories as dependent variable $(\mathrm{N}=23)$ (with absolute t-statistics in parentheses) in 2007.

\begin{tabular}{|c|c|c|c|c|}
\hline $\begin{array}{r}\text { Constant and } \\
\text { variables }\end{array}$ & Coefficients & Coefficients & Coefficients & Coefficients \\
\hline Constant & $\begin{array}{r}7.470766 \\
(51.3) \\
\end{array}$ & $\begin{array}{r}7.320254 \\
(54.7) \\
\end{array}$ & $\begin{array}{r}7.134036 \\
(56.8) \\
\end{array}$ & $\begin{array}{r}6.902721 \\
(56.4) \\
\end{array}$ \\
\hline NM & $\begin{array}{r}0.006906 \\
(4.1)\end{array}$ & $\begin{array}{r}0.007348 \\
(4.4)\end{array}$ & $\begin{array}{r}0.006393 \\
(4.3)\end{array}$ & $\begin{array}{r}0.007592 \\
(5.0)\end{array}$ \\
\hline $\begin{array}{r}\text { BICYCLE*D } \\
\text { RESERVE }\end{array}$ & $\begin{array}{r}-2.68 \mathrm{E}-06 \\
(1.5)\end{array}$ & $\begin{array}{r}-1.64 \mathrm{E}-06 \\
(0.9)\end{array}$ & $\begin{array}{r}-1.44 \mathrm{E}-06 \\
(0.8)\end{array}$ & $\begin{array}{r}-1.85 \mathrm{E}-06 \\
(1.2)\end{array}$ \\
\hline ROADS & $\begin{array}{r}5.21 \mathrm{E}-08 \\
(1.9)\end{array}$ & $\begin{array}{r}2.94 \mathrm{E}-08 \\
(0.9)\end{array}$ & $\begin{array}{r}6.42 \mathrm{E}-08 \\
(2.6)\end{array}$ & $\begin{array}{r}-2.54 \mathrm{E}-08 \\
(1.0)\end{array}$ \\
\hline DOGS & $\begin{array}{r}3.14 \mathrm{E}-07 \\
(0.0)\end{array}$ & $\begin{array}{r}-2.21 \mathrm{E}-05 \\
(0.42)\end{array}$ & $\begin{array}{r}-3.59 \mathrm{E}-05 \\
(0.8)\end{array}$ & $\begin{array}{r}1.74 \mathrm{E}-05 \\
(0.4)\end{array}$ \\
\hline GARDEN & $\begin{array}{r}0.000143 \\
(2.0)\end{array}$ & $\begin{array}{r}9.77 \mathrm{E}-05 \\
(1.4)\end{array}$ & $\begin{array}{r}8.17 \mathrm{E}-05 \\
(1.1)\end{array}$ & $\begin{array}{r}3.57 \mathrm{E}-05 \\
(0.6)\end{array}$ \\
\hline DLOCATION & $\begin{array}{r}0.516074 \\
(1.8)\end{array}$ & $\begin{array}{r}0.448998 \\
(1.8)\end{array}$ & $\begin{array}{r}0.461025 \\
(1.9)\end{array}$ & $\begin{array}{r}0.476807 \\
(2.1)\end{array}$ \\
\hline Adj. $\mathbf{R}^{2}$ & .60 & .67 & .68 & .74 \\
\hline Dep. variable & $\log (\mathrm{PA})$ & $\log (\mathrm{PB})$ & $\log (\mathrm{PC})$ & $\log (\mathrm{PD})$ \\
\hline $\begin{array}{r}\text { Jarque-Bera test } \\
\text { statistic }\end{array}$ & 1.3 & 2.6 & 4.8 & 4.9 \\
\hline
\end{tabular}


reflected in the worst apartment category (D) price in 2007. In 2008, on the other hand, the price effect increases for high (A) and good (B) quality apartments, whereby the highest price impact (also of around 8 percent) is reflected in the high quality apartment category (A).

The existence of bicycle paths in districts with biological reserves either negatively significantly or insignificantly affects housing prices, depending on the apartment type and size (see table 2-3 and 4-5).

The highly significant positive impact of the presence of gardens on the mean district apartment price holds for all categories, except for the worst quality apartment types (C-D). The positive significant impact of the presence of public roads in districts does not apply to all categories.

Furthermore, the positive coefficient of the dummy variable DLOCATION implies that the mean apartment price of central districts is on average higher than that of semicentral and peripheral districts, respectively. However, since there is a correlation between the district size and its distance from the city centre, the variable DLOCATION also correlates to the district size, seeing that on average the central districts are somewhat smaller. Of course, there may be arguments that the density of biological reserves (and the other explanatory variables) - depending on the district size could represent a better indicator of plant species diversity. However, other types of bias would appear, i.e. due to differences in the designation of green areas and since most natural monuments are clustered and not "normally distributed" within a district (with impact on the inhabitants' perceptions of there existence) and the density of biological reserves would be extraordinarily high in smaller districts.

Table 4: $\quad$ Regressions using the average district apartment price per square meters for different apartment categories as dependent variable $(\mathrm{N}=23)$ (with absolute t-statistics in parentheses) in 2008.

\begin{tabular}{|r|r|r|r|r|}
\hline Constant and variables & Coefficients & Coefficients & Coefficients & Coefficients \\
\hline Constant & 7.419729 & 7.276861 & 7.043226 & 6.872185 \\
& $(80.1)$ & $(176.2)$ & $(112.9)$ & $(121.9)$ \\
\hline NM/INH & 442.3865 & 409.4645 & 376.3179 & 378.1669 \\
& $(11.0)$ & $(9.3)$ & $(7.9)$ & $(10.3)$ \\
\hline (BICYCLE*D & -0.241523 & -0.209783 & -0.203623 & -0.175907 \\
RESERVE)/INH & $(3.1)$ & $(2.9)$ & $(2.1)$ & $(2.0)$ \\
\hline ROADS/INH & 0.010727 & 0.006724 & 0.005810 & 0.005362 \\
& $(3.0)$ & $(3.6)$ & $(2.8)$ & $(2.4)$ \\
\hline DOGS/INH & -0.587435 & -0.213836 & 1.285782 & 1.005316 \\
& $(0.2)$ & $(0.1)$ & $(0.4)$ & $(0.4)$ \\
\hline GARDEN/INH & 10.33621 & 7.124827 & 7.953008 & 2.492111 \\
& $(2.5)$ & $(2.5)$ & $(2.5)$ & $(0.7)$ \\
\hline DLOCATION & 0.311124 & 0.272878 & 0.316715 & 0.264529 \\
& $(3.8)$ & $(5.3)$ & $(4.5)$ & $(4.3)$ \\
\hline Adj. R $\mathbf{R}^{2}$ & .92 & .93 & .89 & .91 \\
\hline Dep. variable & $\log (\mathrm{PA})$ & $\log (\mathrm{PB})$ & $\log (\mathrm{PC})$ & $\log (\mathrm{PD})$ \\
\hline Jarque-Bera test & .2 & 3.3 & 5.1 & 5.7 \\
statistic & & & & \\
\hline
\end{tabular}


Table 5: $\quad$ Regressions using the average district apartment price per square meters for different apartment categories as dependent variable $(\mathrm{N}=23)$ (with absolute t-statistics in parentheses) in 2007.

\begin{tabular}{|r|r|r|r|r|}
\hline $\begin{array}{r}\text { Constant and } \\
\text { variables }\end{array}$ & Coefficients & Coefficients & Coefficients & Coefficients \\
\hline Constant & 7.422844 & 7.252005 & 7.104207 & 6.884573 \\
& $(70.0)$ & $(88.0)$ & $(94.2)$ & $(75.2)$ \\
\hline NM/INH & 380.3623 & 445.5702 & 380.6328 & 458.5051 \\
& $(8.0)$ & $(6.6)$ & $(6.5)$ & $(9.7)$ \\
\hline (BICYCLE*D & -0.261243 & -0.216642 & -0.199229 & -0.202817 \\
RESERVE)/INH & $(3.0)$ & $(2.2)$ & $(1.9)$ & $(2.3)$ \\
\hline ROADS/INH & 0.008171 & 0.004091 & 0.007411 & 0.001016 \\
& $(2.3)$ & $(1.1)$ & $(2.8)$ & $(0.3)$ \\
\hline DOGS/INH & 1.305842 & 1.239811 & -1.250274 & 2.133175 \\
& $(0.3)$ & $(0.3)$ & $(0.3)$ & $(0.5)$ \\
\hline GARDEN/INH & 11.28094 & 7.296236 & 6.419130 & -0.543769 \\
& $(2.7)$ & $(1.7)$ & $(1.8)$ & $(0.1)$ \\
\hline DLOCATION & 0.307793 & 0.304025 & 0.294878 & 0.293738 \\
& $(3.5)$ & $(0.1)$ & $(3.7)$ & $(3.6)$ \\
\hline Adj. $\mathbf{R}^{2}$ & .85 & .87 & .87 & .90 \\
\hline Dep. variable & $\log (\mathrm{PA})$ & $\log (\mathrm{PB})$ & $\log (\mathrm{PC})$ & $\log (\mathrm{PD})$ \\
\hline Jarque-Bera test & 2.7 & .36 & 1.7 & .4 \\
statistic & & & & \\
\hline
\end{tabular}

\subsection{Estimation of effect of environmental attributes and neighbourhood characteristics per inhabitant on average housing values per districts}

Since the official urban zoning, in particular the designation of green areas differs extremely within the 23 districts, similar regressions (with higher explanatory power) were run (see table 4 and table 5), dividing all explanatory variables (except for the dummy variable LOC) by the number of inhabitants (INH).

The impact of natural monuments divided by the inhabitants per district compared to the effect of the absolute number of natural monuments per district on the mean district apartment price is about 3.8, 4.5, 3.8 and 4.6 percent in 2007 and 4.4, 4.1, 3.8 and 3.8 percent in 2008, using PA, PB, PC and PD as regressands.

\section{Conclusions}

Natural monuments and gardens play an important role in the private housing market. The price effect of natural monuments per inhabitant is even higher than the impact of natural monuments in absolute numbers per district on the medium district housing price level. Here, natural monuments or plant species diversity, respectively, are a subset of biodiversity, which is generally specified as existence value. Existence values may include some intrinsic value [18], which is not human-held or preference-related, respectively. Most inhabitants may not 
explicitly perceive the existence of natural monuments, in comparison to green areas (as a nonmarket good or service) in which they live, entering in the individuals' utility functions. However, natural monuments could partially enter into the individuals' utility functions, presumably by attributing an additional value to green areas. Therefore, natural monuments - in this case plant species diversity as a subset of biodiversity - can be translated into a market value, although they are to a degree categorised as existence values.

\section{References}

[1] Rosen, S., Hedonic Prices and Implicit Markets: Product Differentiation in Pure Competition. Journal of Political Economy 82, pp. 34-55, 1974.

[2] Samuelson, P. A., A note on the pure theory of consumer's behavior. Economica 5 (17), pp. 61-71, 1938.

[3] Pearce D. W., Turner K. R., Economics of natural resources and the environment, New York (u. a): Harvester Wheatsheaf, 1990.

[4] Wichmann, G., Frank, G., Bestandserhebung der Wiener Brutvögel: Ergebnisse der Spezialkartierung Waldvögel, Studie im Auftrag der Magistratsabteilung 22, Wien, 2003.

[5] Donnerbaum, K., Bestandserhebung der Wiener Brutvögel: Ergebnisse der Spezialkartierung Dohle (Corvus monedula), Studie im Auftrag der Magistratsabteilung 22, Wien, 2003.

[6] Mercer, Mercer's 2008 Quality of Living survey highlights: www.mercer.com/, 2008.

[7] Economist, The, Liveability ranking: Urban idylls, www.theeconomist.com, 2008.

[8] Morancho, A. B., A hedonic valuation of urban green areas, Landscape and Urban Planning 66, pp. 35-41, 2003.

[9] Troy, A., Grove, J. M., Property values, parks, and crime: A hedonic analysis in Baltimore, MD, Landscape and Urban Planning 87, pp. 233$245,2008$.

[10] Gao, X., Asami, Y., Effect of urban landscapes on land prices in two Japanese cities, Landscape and Urban Planning 81, pp. 155-166, 2007.

[11] Rosiers, Des, F., Thériault, M., Kestens, Y., Villeneuve, P., Landscaping and House Values: An Empirical Investigation, Journal of Real Estate Research 2 3, (1/2), 2002.

[12] Freeman, A. M., III., On Estimating Air Pollution Control Benefits from Land Value Studies, Journal of Environmental Economics and Management 1 (1), pp. 77, 1974.

[13] Amrusch, P. and Wirl, F., The Impact of Environmental Conditions on the Housing Market: An International Comparison, Journal of Housing Economics, accepted, 2007.

[14] Chay, K.J., Greenstone, M., Does Air Quality Matter? Journal of Political Economy 113 (2), pp. 376-424, 2005.

[15] Kong, F., Yin, H., Nakagoshi, N., Using GIS and landscape metrics in the hedonic price modeling of the amenity value of urban green space: A case 
424 Ecosystems and Sustainable Development VII

study in Jinan City, China, Landscape and Urban Planning 79, pp. 240252, 2007.

[16] Immobilienpreisspiegel, Fachverband der Immobilien- und Vermögenstreuhänder, Immobilienpreisspiegel, Wirtschaftskammer Österreich: Wien, 2007 and 2008.

[17] Magistrat der Stadt Wien http://www.wien.gv.at/ (2008, 2009)

[18] Attfield, R., Existence value and intrinsic value, Ecological Economics 24, pp. 163-168, 1998. 